\title{
Analisis Keberhasilan Usaha Kecil dan Dampaknya Terhadap Pendapatan Keluarga di Kota Jambi
}

\author{
Fahrizal \\ Program Studi Ilmu Komunikasi, Sekolah Tinggi Ilmu Sosial dan Ilmu Politik (STISIP) Nurdin Hamzah \\ Correspondence email: idfahrizaljambi@gmail.com
}

\begin{abstract}
The roles of small enterprises in supporting economic growth, either covering locally or nationally, may not be taken for granted. It is proven by the fact that when Indonesia was stricken by an economic crisis the small enterprises relatively stable. In reality, however, they have been facing many problems, one of which is the source of found/capital. In addition, they also lack basic skills in financial and business management. Generally, most of them are secondary school graduates. In Jambi, the number of small and medium enterprises reaches 2730 with 35.950 employees employed. Such a number is already potentially sufficient to improve the economic growth of the region. Thus, a study regarding the existence of small enterprises in Jambi should be conducted. The study itself should mainly be focused on the problems found in running such kind of enterprises. A study was conducted in December 2015 to February 2016 in Jambi city, taking the cases from the Jelutong subdistrict. The objects of the study were small enterprises including grocery stores. Snacks shops, and furniture depots. The variables studied included the successes of small enterprises (enterprise volume), household income rates, entrepreneurial experiences, educational levels, domestic expenditures, and access to the bank. Based on the result of the study, it is acknowledged that capitals and educational levels strongly determine the success of small enterprises. Therefore, to boots, their involvement in Jambi city, especially at the Jelutung subdistrict, support from related institutions are essentially needed. Such support may include improving the small entrepreneurs' knowledge and skills in business and financial management. Besides, the source of found/capital should also be taken into account.
\end{abstract}

Keywords: UKM; income; family

\section{PENDAHULUAN}

Usaha kecil merupakan salah satu bidang usaha yang memberikan kontribusi terhadap pertumbuhan ekonomi suatu daerah. Dalam perkembangan ekonomi Indonesia, usaha kecil mampu berkontribusi dalam meningkatkan daya saing global dan membuka aksesibilitas terhadap penyerapan tenaga kerja dan berusaha bagi segenap rakyat dan seluruh daerah. Melalui keunggulan kompetitif yang berbasis keunggulan sumberdaya alam dan sumberdaya manusia, usaha kecil dapat diandalkan untuk menciptakan lapangan kerja seluas-luasnya bagi penyerapan tenaga kerja dan perbaikan pertumbuhan ekonomi.

Krisis ekonomi yang melanda Indonesia beberapa waktu lalu telah menimbulkan berbagai dampak yang cukup berpengaruh kepada kehidupan masyarakat. Kecenderungan kenaikan harga yang terjadi tidak diikuti peningkatan daya beli masyarakat. Hal ini disebabkan terbatasnya sumber-sumber yang dapat diusahakan masyarakat guna mencari penghasilan ataupun sebagai tambahan penghasilan masyarakat. Salah satu alternatif pemecahan masalah lapangan kerja tersebut adalah dengan meningkatkan pertumbuhan ekonomi diantaranya adalah pembangunan usaha kecil dan rumah tangga. Melalui pembangunan usaha kecil diharapkan menjadi perisai yang tangguh dalam membentengi kekuatan ekonomi nasional. Peranan usaha kecil di Indonesia diakui sangat penting dalam perekonomian nasional, terutama dalam aspek-aspek seperti peningkatan kesempatan kerja, pemerataan pendapatan, pembangunan ekonomi pedesaan dan peningkatan ekspor non migas. Selama ini telah banyak usaha yang dilakukan oleh pemerintah untuk membantu perkembangan usaha kecil melalui berbagai macam program pengembangan atau pembinaan usaha kecil termasuk di antaranya adalah program kemitraan antara usaha menengah dan besar dengan usaha kecil. Namun demikian, perkembangan usaha kecil hingga saat ini berjalan sangat lamban. Sebagai contoh, di sektor industri manufaktur, tingkat produktivitas atau konstribusi output industri kecil dan rumah tangga terhadap pembentukan total nilai tambah di sektor tersebut atau produk domestik bruto masih relatif rendah dibandingkan dengan industri menengah dan besar.

Salah satu penyebab kurang berhasilnya program pengembangan atau pembinaan usaha kecil di Indonesia dalam memperbaiki kondisi atau kinerja kelompok usaha kecil, dari posisi yang lemah dan tradisional ke posisi yang kuat dan moderen adalah tekanan berbagai faktor baik internal maupun eksternal sulit dipecahkan oleh pengusaha kecil itu sendiri. Sementara di satu sisi orientasi program atau kebijakan pemerintah dalam membantu usaha kecil lebih terletak pada "aspek sosial" daripada "aspek ekonomi atau bisnis". Di Kota Jambi jumlah usaha kecil cukup berkembang, baik dari jumlah usaha maupun penyerapan tenaga kerjanya sebagaimana tergambar pada tabel berikut : 
Tabel 1

Perkembangan Jumlah Usaha Kecil di Kota Jambi 2000-2015

\begin{tabular}{crrrr}
\hline Tahun & Jumlah Usaha Kecil (unit) & Pertumbuhan (\%) & TK (jiwa) & Pertumbuhan (\%) \\
\hline 2000 & 271 & - & 7.207 & - \\
2005 & 431 & 59,04 & 10.492 & 45,58 \\
2010 & 851 & 97,48 & 14.507 & 38,27 \\
2015 & 2730 & 220,80 & 35.950 & 147,81 \\
& & 115,77 & & 77,22 \\
\hline
\end{tabular}

Sumber: Dinas Koperasi, Usaha Kecil dan Menengah Kota Jambi Tahun 2016.

Berdasarkan tabel 1 tergambar bahwa selama periode 2000-2015 jumlah unit usaha-usaha kecil di Kota Jambi rata-rata mengalami perkembangan sebesar 115,77 persen, sementara dalam periode yang sama jumlah tenaga kerja yang mampu diserap oleh usaha kecil di Kota Jambi mengalami pertumbuhan rata-rata sebesar 77,22 persen. Dari jumlah usaha kecil di atas terbagi pada beberapa kelompok usaha kecil, di antaranya adalah usaha makanan ringan, kerajinan tangan, kerajinan perabotan, minuman ringan, batik, pertukangan, toko kelontong, dan sebagainya. Pertumbuhan usaha kecil dan rumah tangga akan menimbulkan dampak positif terhadap peningkatan jumlah tenaga kerja, pengganguran, jumlah kemiskinan, pemerataan dalam distribusi pendapatan, dan pembangunan ekonomi di pedesaan/ daerah (Arifin, 2004 ). Dari sisi kebijakan usaha kecil dan rumah tangga jelas perlu mendapat perhatian karena tidak hanya memberikan penghasilan bagi sebagian besar angkatan kerja Indonesia, namun juga merupakan ujung tombak dalam upaya pengentasan kemiskinan dan peningkatan kualitas hidup masyarakat. Diharapkan, dengan pengembangan usaha kecil tersebut terjadi peningkatan pendapatan keluarga sebagai akibat berkembangnya usaha kecil itu sendiri sehingga cita-cita mewujudkan keluarga sejahtera dapat tercapai. Disamping itu pengembangan usah kecil tersebut juga diharapkan berimplikasi terhadap lapangan usaha dan penyerapan tenaga kerja secara keseluruhan.

\section{Studi Literatur}

\section{Usaha Kecil Menengah}

Menurut Kadin dan Asosiasi serta Himpunan Pengusaha Kecil serta Kriteria Bank Indonesia, maka yang termasuk dalam kategori Usaha-Kecil adalah: a. Usaha Perdagangan : Pengecer, keagenan, eksport/import, b. Usaha Pertanian: pertanian pangan maupun perkebunan, perikanan laut/darat, peternakan dan usaha lain, c. Industri logam/kimia, makanan/minuman pertambangan, bahan galian, aneka industri kecil lain, d. Usaha Jasa : menjual tenaga/pelayanan bagi pihak ketiga, konsultan, perencana, perbengkelan, transportasi, serta restoran dan lainnya. e. Usaha Jasa : Kontraktor bangunan, jalan, kelistrikan, jembatan, pengairan, dan usaha lainnya (Harimurti Subanar, 2001). Sehubungan dengan perkembangan lingkungan perekonomian yang semakin dinamis dan global, UndangUndang Nomor 9 Tahun 1995 tentang Usaha Kecil, yang hanya mengatur Usaha Kecil perlu diganti, agar Usaha Mikro Kecil dan Menengah di Indonesia dapat memperoleh jaminan kepastian dan keadilan usaha (UU RI Nomor 20 Tahun 2008). Selanjutnya menurut Undang-Undang UMKM Tahun 2008 (UU RI Nomor 20 Tahun 2008) Bab IV Pasal 6 menyebutkan tentang Kriteria dari Usaha Mikro, Kecil, dan Menengah adalah sebagai berikut: 1. Kriteria Usaha Mikro adalah sebagai berikut: (a) memiliki kekayaan bersih paling banyak Rp. 50.000.000,- (lima puluh juta rupiah) tidak termasuk tanah dan bangunan tempat usaha ; atau (b) memiliki hasil penjualan tahunan paling banyak Rp. 300.000.000,- (tiga ratus juta rupiah). 2. Kriteria Usaha Kecil adalah sebagai berikut : (a) memiliki kekayaan bersih lebih dari Rp. 50.000.000,- (lima puluh juta rupiah) sampai paling banyak Rp.500.000.000,- (lima ratus juta rupiah) ) tidak termasuk tanah dan bangunan tempat usaha; atau (b) memiliki hasil penjualan tahunan lebih dari Rp. 300.000.000,- (tiga ratus juta rupiah) sampai paling banyak Rp. 2.500.000.000,- (dua milyard lima ratus juta rupiah). 3. Kriteria Usaha Menengah adalah sebagai berikut : (a) memiliki kekayaan bersih lebih dari Rp. 500.000.000,- (lima ratus juta rupiah) sampai paling banyak Rp. 10.000.000,- (sepuluh milyard rupiah) tidak termasuk tanah dan bangunan tempat usaha atau; (b) memiliki hasil penjualan tahunan lebih dari Rp. 2.500.000.000,- (dua milliar lima ratus juta rupiah) sampai paling banyak Rp. 50.000.000.000,- (lima puluh milyar rupiah). Pada hakekatnya usaha kecil yang ada secara umum dikelompokkan ke dalam 3 (tiga) golongan khusus yang meliputi: (Harimurti Subanar, 2001) a. Industri Kecil: Industri kerajinan rakyat, industri cor logam, konveksi dan berbagai industri lainnya. b. Perusahaan berskala kecil: penyalur, toko kerajinan, koperasi, waserba, restoran, toko bunga, jasa profesi dan lainnya. c. Sektor informal: agen barang bekas, kios kaki lima dan lainnya. Menurut Pius Bumi K (2004) secara umum usaha kecil dan menengah memiliki karakteristik antara lain: (1) Sistem pembukuan yang sederhana, (2) Marjin usaha yang tipis karena persaingan yang sangat tinggi, (3) Modal terbatas, (4) Pengalaman manejerial yang terbatas. Selain itu, usaha kecil dan menengah juga tergolong dalam usaha rumahan.

Menurut Saleh (2003) usaha kecil adalah suatu bentuk usaha yang mampu menyerap tenaga kerja antara 5 - 40 orang. Sementara Cahyono (1993) mengungkapkan bahwa di Indonesia kriteria pengusaha usaha kecil adalah pengusaha yang memiliki kekayaan bersih tidak melebihi Rp. 40.000.000,- . Dimana kekayaan tersebut tidak termasuk rumah dan tanah yang ditempati, dan hasil penjualan usahanya rata-rata dalam satu bulannya tidak melebihi nilai Rp. 
10.000.000,- sedangkan menyatakan Tambunan (1999) usaha kecil yaitu suatu unit usaha dengan jumlah tenaga kerja 5-19 orang. Usaha kecil pada umumnya memiliki ciri-ciri: (1) Sebagian pekerja adalah anggota keluarga (istri dan anak) yang tidak dibayar: (2) Proses produksi dilakukan secara manual dan kegiatannya sehari-hari berlangsung di rumah; (3) Kegiatan produksi sangat musiman mengikuti kegiatan produksi di sektor pertanian yang juga umumnya musiman; dan (4) Jenis produksi yang dihasilkan umumnya dikategorikan barang-barang konsumsi sederhana.

Sektor usaha kecil ditandai oleh satuan usaha dalam jumlah yang banyak. Biasanya dimiliki, dikelola dan memakai tenaga kerja keluarga, upah dibayar tidak seperti sektor usaha lainnya. Golongan tenaga kerja disektor usaha kecil yang dikelola kecil ini merupakan golongan kerja mandiri. Kegiatan dalam satuan usaha dilakukan tanpa peralatan modal yang memadai. Dalam sektor usaha kecil kadang tidak didukung oleh kemudahan-kemudahan yang tersedia seperti usaha di sektor lainnya, pendapatannya mungkin cukup untuk mempertahankan pada tingkat yang lebih rendah. Pada tingkat kegiatan usaha ada dua kondisi utama yang perlu dipenuhi, yaitu : pertama, lingkungan internal dari dalam kegiatan usaha harus kondusif yang mencakup banyak aspek mulai dari kekuatan modal, lama uaha, pendidikan, alokasi waktu yang digunakan dalam menjalankan usaha dan tidak kalh pentingnya dukungan suami. Kedua, lingkungan eksternal mencakup aspek kebijakan pemerintah seperti bantuan, baik bantuan langsung berupa modal atau bantuan yang besifat teknis, kemudian dalam akses terhadap modal dan kemitraan.

Dewasa ini kegiatan sektor usaha kecil yang dikelola pengusaha kecil menjadi sanggat penting. Bagaimanapun juga sektor ini telah menjadi sumber tambahan pendatan kelurga. Searah dengan perkembangan jumlah usaha kecil yang ada dan peningkatan pendapatan keluarga maka diharapkan juga terjadi peningkatan dan pemerataan distribusi pendapatan serta meningkatnya kontribusi terhadap Produk Domestik Regional Bruto (PDRB). Namun demikian, pencapaian kedua hal tersebu bersamaan tidak terjadi. Hal ini disebabkan terhadap bermacam faktor penting yang dapat mempengaruhi pengembangan suatu kegiatan usaha (usaha kecil). Untuk itu diperlukan satu kajian yang lebih mendalam melalui proses penelitian, faktor-faktor apa saja dan bagaimana faktor-faktor atau variabel-variabel tersebut bekerja sehingga berdampak terhadap kesejahteraan keluarga dalam pengembangan usaha kecil. Didasari begitu besarnya peran usaha kecil yang dikelola pengusaha kecil dalam perekonomian nasional, maupun dalam menyerap tenaga kerja, dalam pemerataan distribusi hasil-hasil pembangunan, maka pemerintah melalui undang-undang nomor 09 tahun 1995, memberikan batasan terhadap usaha kecil adalah usaha yang (1) Memiliki kekayaan (asset) bersih paling banyak Rp.200 juta, tidak termasuk tanah dan bangunan tempat usaha; (2) memliki hasil penjualan (omzet) tahunan paling banyak Rp. 1 milyar; (3) milik warga negara Indonesia; dan (4) berdiri sendiri, bukan merupakan anak kegiatan usaha atau cabang kegiatan usaha .

\section{Pendapatan}

Setiap aktivitas usaha senantiasa mengharapkan keuntungan. keuntungan dapat diperoleh apabila penerimaan yang dihasilkan melebihi biaya yang dikeluarkan. Dalam konteks rumah tangga pendapatan menurut Lissey (2001) terdiri dari pendapatan nyata dan pendapatan berupa uang. Pendapatan berupa uang adalah pandapatan yang diukur dengan unit-unit uang, dalam kurun waktu, sedangkan pendapatan nyata dari suatu rumah tangga adalah tenaga daya beli pendapatan yang berupa uang, yaitu jumlah barang-barang yang dapat di beli dengan sejumlah pendapatan tersebut. Badan Pusat Statistik (BPS) mendefinisikan pendapatan rumah tangga sebagai seluruh penerimaan yang didapat setiap rumah tangga atau balas jasa faktor-faktor ekonomi (Anonim, 2000). Ada keterkaitan yang erat antara pendapatan, faktor produksi dan tingkat kesejahteraan suatu rumah tangga. Pendapatan adalah hasil berupa uang atau hasil materil lainnya yang dicapai dari pada penggunaan kekayaan atau jasa-jasa manusia bebas (Partadireja, 2005). Mengenai pendapatan yang dimaksud di sini adalah pendapatan oleh masing-masing rumah tangga yang diterima ratarata setiap bulannya. Pendapatan tersebut baik berupa uang atau barang, disamping itu perhitungan pendapatan didapatkan secara langsung dengan memperhitungkan gaji pokok di tambah dengan harga pergantian natura, biaya transport, serta tunjangan atau gaji pokok dalam hubungan dengan jumlah anggota keluarga dan masa kerja.

Pengertian pendapatan rumah tangga di atas mempunyai arti bahwa pendapatan terdiri dari pendapatan dalam bentuk uang dan barang yang memiliki nilai yang sama dengan uang. Namun demikian dalam konteks usaha tani penerimaan dapat berupa hasil panen dan dalam bentuk uang apabila telah dijual. Menurut Partadireja (2005) penerimaan keluarga adalah penerimaan dari semua sumber usaha keluarga yang meliputi: Jumlah penambahan inventaris, Nilai penjualan hasil, Harga pembelian dikurangi penyusutan. Mubyarto (1999) mengemukakan bahwa pendapatan adalah seluruh penerimaan baik berupa uang atau barang dari hasil usaha atau produksi. Sementara pendapatan rumah tangga dapat diartikan sebagai jumlah keseluruhan dari pendapatan formal, informal dan sub-sub sistem. Pendapatan formal adalah adalah penghasilan yang diperoleh melalui pekerjaan pokok, sedangkan pendapatan informal diperoleh melalui pekerjaan di luar pekerjaan pokok. Pendapatan senada dikemukakan oleh BPS yang mendifinisikan pendapatan rumah tangga sebagai seluruh penerimaan yang di dapat setiap rumah tangga atau balas jasa foktor-foktor ekonomi (Anonim, 2000).

Menurut Sukartawi (1995) perubahan tingkat pendapatan akan mempengaruhi banyaknya barang yang akan 
dikonsumsi, pada tingkat pendapatan rumah tangga yang rendah, maka pengeluaran rumah tangga lebih besar dari pendapatannya. Hal ini berarti pengeluaran konsumsi bukan hanya dibiayai dari pendapatan mereka saja, tetapi juga dari sumber lain seperti tabungan yang dimiliki, menjual harta benda atau dari pinjaman. Semakin tinggi tingkat pendapatan maka konsumsi yang dilakukan rumah tangga akan semakin besar pula. Bahkan sering kali di jumpai dengan bertambahnya pendapatan, maka barang yang dikonsumsi bukan hanya bertambah akan tetapi kualitas barang yang dimintapun bertambah.

Menurut Todaro (2000) distribusi pendapatan adalah ukuran pendapatan yang digunakan dalam menghitung jumlah penghasilan yang diterima oleh setiap individu atau rumah tangga. Disisi lain Arsyad (2001) mendifinisikan distribusi pendapatan sebagai hubungan antara individu-individu dengan pendapatan total yang mereka terima. Pendapatan adalah balas jasa yang diterima pemilik faktor produksi atas penggunaan faktor-faktor produksi seperti tanah, modal, dan skill yang dimilikinya. Penggunaan tanah diberikan balas jasa yang disebut sewa, tenaga kerja yang diberi upah atau gaji, modal diberi bunga dan skilldiberi keuntungan, dan keuntungan ini adalah pegembalian penggunaan faktor-faktor produksi (Hasibuan, 2001). Selanjutnya Kuncoro (2002) mengatakan bahwa tingkat pendapatan adalah salah satu indikator ekonomi dan tercakup dalam pengertian tingkat hidup. Dalam pengertian yang luas adalah kesejah teraan, untuk mengukurnya memerlukan sejumlah indikator selain indikator ekonomi. Pendapatan merupakan faktor penting dalam permintaan suatu barang. Semakin besar pendapatan semakin besar pula jumlah barang yang diminta. Pendapatan juga berguna sebagai ukuran dari tingkat penghidupan perkonomian dari suatu masyarakat. Jika pendapatan dalam suatu masyarakat meningkat berarti semakin tinggi pula tingkat pertumbuhan ekonomi.

\section{Faktor yang Mempengaruhi Keberhasilan Usaha Kecil}

\section{Modal yang berasal dari asset rumatangga}

Permodalan merupakan faktor utama yang diperlukan untuk mengembangkan suatu unit usaha. Umumnya usaha kecil merupakan usaha perseorangan atau kegiatan usaha yang sifatnya tertutup, yang mengandalkan pada modal dari sipemilik yang jumlahnya sanggat terbatas, sedangkan modal pinjaman dari bank atau lembaga keuangan lainnya sulit di peroleh, karena persyaratan secara administrasi dan teknis yang diminta oleh bank tidak dapat dipenuhi oleh usaha kecil. Arti modal dalam sejarahnya berkembang, sesuai dengan perkembangan artian modal itu sendiri secara secara ilmiah. Pada nilainya, orientasi dari pengertian modal adalah physical oriented. Dalam perkemabnagannya kemudian ternyata pengertian modal adalah bersifat non physical oriented. Pengertian modal ditekankan pada nilai, daya beli, atau kekuasaan memakai yang terkandung dalam barang-barang modal, meskipun dalam hal ini sebenarnya juga belum ada persesuaian pendapatan diantara para ahli ekonomi. Beberapa pengertian modal menurut para ahli adalah Lutge menulis, modal hanyalah dalam artian uang. Scheidland dalam Heru (2000) memberikan pengertian modal yang lebih luas dimana modal itu meliputi baik modal dalam bentuk uang maupun dalam bentuk barang, misalnya mesin-mesin, barang-barang dagangan dan sebagainya. Beker dalam Heru (2000) mengartikan modal ialah baik yang berupa barang-barang konkrit yang masih ada dalam rumah tangga pengusaha yang terdapat di neraca sebelah debet, maupun berupa daya beli dari barang-barang itu tercatat disebelah kredit neraca. Uraian tentang modal di atas, dapat disimpulkan bahwa usaha bisnis (termasuk usaha kecil) selalu membutuhkan modal usaha untuk membiayai operasi sehari-hari, misalnya untuk memberikan persekot pembelian barang dagang, membayar upah kerja, membayar uang keamanan dan lain-lain. Dalam mengembangkan usaha kecil, permasalahan utama yang dihadapi adalah kesulitan modal, hal ini disebabkan karena keterbatsan asset yang dimiliki oleh pengusaha tersebut. Untuk mengatasi kesulitan modal itu, tidak cukup hanya menyediakan fasilitas kredit, memberikan bantuan teknis dan pembinaan oleh pemerintah saja, akan tetapi diperlukan unsur pendukung lainnya. Unsur pendukung lain tersebut ialah bentuk kerjasama dengan kegiatan usaha besar baik swasta maupun BUMN, sehingga terwujud proses alih manajemen dalam pengelolaan usaha kecil/ usaha sektor informal. Kenyataan menunjukkan bahwa proses alih menajemen tersebut sulit dilakukan melalui kebijaksanaan pemerintah secara konvensional. Karena itu lah : program kemitraan" menjadi unsur yang sangat strategis dan menentukan dalam pengeambangan usaha sektor informal (Indra, 2002).

\section{Pendidikan dan Sumber Daya Manusia.}

Menurut Todaro 2000, sumberdaya manusia merupakan modal dasar kekayaan bangsa, sedangkan sumberdaya yang lain yakni sumberdaya fisik maupun sumberdaya alam adalah faktor produksi yang bersifat pasif. Funsi manusia dalam ekonomi adalah pengumpulan modal, mengeksploitasi sumberdaya alam, membangun organisasiorganisasi sosial, ekonomi maupun organisasi politik; serta melakukan pembangunan nasional. Terhadap statu negara yang tidak mengembangkan keahlian dan pengetahuan rakyatnya dan atau tidak mampu memanfaatkan sumberdaya manusia mereka secara efektif maka negara bersangkutan tidak akan dapat mengembangkan apapun. Apabila ditinjau dari segi ilmu ekonomi dan kesempatan kerja akan berputar pada dua proses ekonomi yang fundamental yakni: (a) Interaksi antara permintaan yang hermotivasi ekonomi dengan penawaran sebagi hasil reaksi politik sangat menentukan besarnya investasi serta muatan ilmu/keterampilan di bidang pendidikan; dan (b) 
Pentingnya perbedaan antara manfaat social dan pribadi dalam pendidikan. Sebagai derived demand, permintaan akan pendidikan sangat ditentukan oleh empat variabel yakni: a). tingkat pendapatan penghasilan upah, 2). Kemungkinan mendapatkan pekerjaan disektor moderen, c). biaya pendidikan bersifat langsung serta, d). Biaya pendidikan bersifat tidak langsung atau biaya oportunitis.

\section{Jam Kerja}

Menurut Soeroto (1986) jam kerja adalah setiap orang mampu memanfaatkan waktu kerja, baik didalam maupun diluar hubungan kerja guna menghasilkan barang atau jasa untuk memenuhi kebutuhan masyarakat. Menurut Volk dalam Artoyo (2001) juga mendefinisikan pekerjaan dalam arti ekonomik. Menurutnya pekerjaan dalam arti ekonomik adalah setiap tindakan dari pikiran dan badan ditujukan untuk mencapai kesenangan dari usaha tersebut. Dumairy (2007) menyatakan bahwa untuk melihat kinerja dari suatu usaha dalam hubungannya dengan kesejahteraan tenaga kerja maka perlu ditelaah lebih lanjut beberapa indikator yang mempengaruhiinya, yaitu tingkat upah/gaji, produktivitas, intensitas penggunaan jam kerja dan efisiensi produksi serta gross margin industri. a. Tingkat Upah/Gaji

Tingkat upah menunjukkan jumlah yang diterima oleh pekerja dari tempatnya bekerja. Semakin tinggi tingkat upah berarti semakin besar jumlah yang diterima oleh pekerja. (Dumairy, 2007). Menurut Samuelson, Lipsey, Steiner dan Purvis dalam Purba, (2005) tingkat upah merupakan rasio antara biaya tenaga kerja yang dikeluarkan oleh industri terhadap jumlah tenaga kerja industri dalam kurun waktu 1 tahun. Semakin besar rasio tersebut menunjukkan semakin besar balas jasa yang diberikan industri terhadap tenaga kerja. pah terendah pada tahun 1990 adalah di industri tekstil, pakaian jadi dan kulit, sementara upah di industri perkayuan masih berada di urutan ke enam.

b. Produktivitas Tenaga Kerja

Poduktivitas tenaga kerja mencerminkan jumlah yang disumbangkan oleh pekerja kepada kegiatan usaha atau industri tempat kerja. Semakin tinggi produktivitas tenaga kerja baik yang diukur berdasarkan nilai keluaran maupun nilai tambah, berarti semakin besar jumlah yang disumbangkan oleh pekerja. Produk yang dihasilkan dalam suatu industri merupakan kombinasi berbagai jenis masukan yang digunakan. Kemampuan masukan menghasilkan sejumlah produk tersebut produktivitas. Jadi produktivitas adalah rasio antara produk yang dihasilkan dengan masukan yang digunakan. Jika hasil rasio tersebut menggunakan semua jenis masukan maka disebut dengan produksi total. Jika hanya menggunakan satu jenis masukan disebut produktivitas parsial. Konsep produktivitas yang lain adalah produktivitas rerata yaitu rasio keluaran-masukan secara fisik, biasanya secara parsial. Sedangkan produktivitas marginal merupakan perubahan keluaran terhadap perubahan masukan. Produktivitas tenaga kerja dapat dipengaharui oleh beberapa faktor, yaitu: kualitas dan kemampuan tenaga kerja yang dipengaharui oleh tingkat pendidikan, latihan, motivasi kerja dan kemampuan fisik tenaga kerja jyang bersangkutan; sarana pendukung yang menyangkut teknoligi dan cara produksi, sistem pengupahan dan jaminan sosial; dan supra sarana meliputi hubungan antara pengusaha dan karyawan yang baik.

c. Intensitas Tenaga Kerja

Intensitas penggunaan jam kerja dalam suatu proses produksi merupakan rasio antara jumlah upah/gaji yang diterima oleh tenaga kerja terhadap total nilai tambah dari suatu produksi. Rasio ini disebut juga dengan koefisien jam kerja. Kenaikan rasio tersebut akan menyebabkan penurunan intensitas tenaga kerja. Berarti sejumlah nilai tambah yang sama diperoleh dengan upah/gaji yang lebih besar dan sebaliknya. Intensitas jam kerja bertujuan untuk meningkatkan nilai tambah dari proses produksi. Semakin tinggi nilai tambah yang dapat dikerjakan tenaga kerja maka akan mendorong semakin besar keuntungan yang diperoleh dari kegiatan produksi atau aktivitas usaha.

\section{Kemitraan}

Salah satu ciri sektor usaha kecil adalah memiliki struktur pasar yang sangat kompetitif. Olah karena itu, untuk menghadapi persaingan tersebut pengusaha harus melakukan suatu strategi bersaing dengan cara bekerjasama, baik sesama usaha kecil maupun dengan usaha yang lebih besar. Kerjasama tersebut diartikan sebagai suatu bentuk kemitraan untuk menciptakan keunggulan kompetitif dari masing-masing pihak yang membentuk kerjasama. Pengalaman di negara-negara berkembang lainnya telah menunjukkan bahwa aliansi strategi (kemitraan) antara usaha kecil dan usaha besar merupakan mekanisme paling penting dan efektif untuk alih informasi bisnis, teknoligi, kemampuan manejerial dan organisatoris, serta akses ke pasar ekspor. Aliansi strategi (kemitraan) ini pada dasarnya merupakan jaringan hubungan bisnis yang informal dan berjangka panjang dalam sektor swasta yang didasarkan atas dasar saling percaya (The Asia Foundation, 2000). Dengan kata kata lain, aliansi strategis merupakan cara yang baik bagi usaha kecil untuk mengakses berbagai hal yang tidak mungkin atau sulit dilaksanakan oleh usaha kecil secara sendiri (Shauki, 2000). Menurut Sauki, bahwa kenerja finansial usaha kecil yang telah membentuk aliansi strategi lebih baik ketipang kinerja finansial usaha kecil yang tidak membentuk aliansi strategi. 


\section{Jumlah anak}

Menurut Beker (1988) anak merupakan barang konsumsi tahan lama (durable goods). Orang tua mempunyai pilihan antara kualitas dan kuantitas, kualitas diartikan sebagai pengeluaran (biaya) rata-rata anak oleh suatu keluarga yang didasarkan atas dua asumsi: (1) Selera orang tua yang tidak berubah dan (2) Harga anak dan barangbarang konsumsi lainnya tidak dipengaruhi oleh keputusan rumah tangga untuk berkonsumsi. Hal ini berarti semakin besar pengeluaran untuk pemeliharaan anak maka semakin tinggi pula kualitas anak (walaupun tolak ukurnya belum jelas). Dalam jangka panjang kenaikan pendapatan akan meningkatkan jumlah pengeluaran anak. Becker berpendapat bahwa bila pendapatan naik banyaknya anak yang dimiliki keluarga juga akan bertambah, jadi hubungan antara pendapatan dan fertilitas adalah positif. Disisi lain bila anak dianggap sebagai barang konsumsi yang tahan lama, atau barang investasi, maka perlu dipikirkan berapa nilainya, ada dua macam beban ekonomi anak ( Robinson dan Horlacer dalam David Lucas (2004)

a. Beban finansial atau beban biaya pemeliharaan langsung : jumlah biaya yang dikeluarkan oleh orang tua untuk makanan, pakaian, perumahan, pendidikan dan perawatan kesehatan anak.

b. Biaya alternatif (Opportunity Cost), biaya yang dikeluarkan atau penghasilan yang hilang karena mengasuh anak. Apabila seorang istri melepaskan pekerjaannya ketika anak-anaknya masih kecil. Maka orang tua akan kehilangan gaji yang seharusnya dia terima jika bekerja.

Menurut Mincer (2003) bahwa efek dari pendapatan adalah positif terhadap jumlah anak, dimana kenaikan pendapatan keluarga akan menyebabkan kecenderungan kelahiran meningkat karena perbaikan standar hidup dan gizi.

\section{METODE}

Penelitian ini mengambil lokasi di Kota Jambi, dengan studi kasus di Kecamatan Jelutung. Waktu penelitian berlangsung dari Bulan Desember 2015 sampai Bulan Februari 2016. Metode penelitian yang digunakan dalam penelitian ini adalah metode penelitian survey. Penelitian survey yang dimaksud adalah penelitian yang mengambil sampel dari suatu populasi dan menggunakan kuesioner sebagai alat pengumpulan data yang pokok atau primer (Singarimbun, 2006). Data pokok yang dimaksudkan dalam penelitian ini adalah data yang langsung diperoleh dari pengusaha kecil yang menjadi sampel yang meliputi besarnya volume usaha, modal usaha, pengalaman berusaha, tingkat pendidikan formal pengusaha kecil, jumlah tanggungan keluarga dan ada tidaknya akses pengusaha kecil terhadap lembaga perbankan dalam hal menyangkut permodalan untuk mengembangkan usaha, serta pendapatan usaha kecil. Sedangkan data sekunder sebagai data penunjang dihimpun dari berbagai sumber seperti, Bad an Pusat Statistik, Dinas Perindustrian Perdagangan dan Koperasi dan beberapa instansi terkait lainnya, serta dari hasil-hasil penelitian sejenis.

Untuk mendapatkan data yang dapat mewakili usaha kecil maka dilakukan penarikan sampel. Metode penarikan sampel yang digunakan adalah Cluster random sampling, dengan jumlah sampel dihitung berdasakan Slavin (Umar, 2004) dengan rumus sebagai berikut:

$\mathrm{n}=\frac{N}{1+N e^{2}}$

$\mathrm{n}=$ Ukuran atau jumlah sampel keseluruhan; $\mathrm{N}=$ Jumlah populasi usaha kecil; $\mathrm{e}=$ Presesi yang diharapkan $(10$ persen)

Maka dapat ditentukan besarnya pengusaha kecil yang dijadikan sebagai sampel dalam penelitian ini sebanyak 92 item. Penentuan sampel dari setiap jenis kelompok usaha dilakukan secara proporsional sebagai berikut:

Tabel 2

Penentuan Jumlah Sampel Penelitian Berdasarkan Kelompok Usaha di Kecamatan Jelutung Kota Jambi.

\begin{tabular}{lrrr}
\hline \multicolumn{1}{c}{ Kelompok Usaha } & Jumlah Populasi & Jumlah Sampel & \\
\hline Toko Kelontong & 976 & 97 \\
Makanan Ringan & 112 & 9 \\
Perabotan & 76 & 6 \\
Jumlah & 1.164 & 92 \\
\hline
\end{tabular}

Untuk menguji faktor-faktor yang mempengaruhi keberhasilan usaha kecil atau volume usaha kecil di Kecamatan Jelutung Kota Jambi digunakan persamaan atau model analisis regresi linier berganda. Pendekatan model analisis ini dapat dapat menjelaskan hubungan antara $\mathrm{Y}$ sebagai variabel dependent dan $\mathrm{Xi}$ sebagai variabel independent yang diformulasikan dengan model penduga berikut (Walpole, 2001): Adapun model yang dimaksud adalah sebagai berikut :

$Y=\beta_{0}+\beta_{1} X_{1}+\beta_{2} X_{2}+\beta_{3} X_{3}+\beta_{4} X_{4}+\beta_{5} X_{5}+$ ei

Dimana : $\beta_{0}=$ Konstanta; $\beta_{1-5} \quad=$ Koefisien regresi; $Y=$ Volume Usaha (Variabel dependent)

Sedangkan variabel independent mencakukup faktor-faktor berikut: $\mathrm{X}_{1}=$ Modal usaha; $\mathrm{X}_{2}=$ Lama usaha; $\mathrm{X}_{3}=$ 
Pendidikan formal; $\mathrm{X}_{4}=$ Tanggungan keluarga; $\mathrm{X}_{5}=$ Akses Bank (variabel dummy); ei $=$ error

Berdasarkan model regresi linier berganda di atas, beberapa hasil analisis yang berkaitan dengan hubungan antara variabel $\mathrm{X}$ dan $\mathrm{Y}$ dalam penelitian ini dapat menjelaskan beberapa aspek yang meliputi:

a. Besaran nilai $\mathrm{R}^{2}$ (koefisien determinasi) yakni suatu besaran yang menjelaskan seberapa besar pula sebaran nilai volume usaha dari usaha kecil yang diamati ditentukan oleh variabel independent yang dikaji.

b. Besaran nilai $\beta$ (koefisien regresi) untuk setiap variabel independent yang terlibat dalam model penduga yang menjelaskan seberapa besar kenaikan atau penurunan volume usaha dari usaha kecil di Kecamatan Jelutung Kota Jambi untuk setiap penambahan satu satuan masing-masing variabel independent yang dikaji.

c. Besaran nilai Probabilitas (P) yang menjelaskan pengaruh suatu faktor, baik secara simultan (bersama-sama) maupun secara parsial (individu ), terhadap variabel dependent yang dikaji hubungannya menurut model regresi.

Untuk menguji hipotesis pengaruh volume usaha terhadap pendapatan keluarga pengusaha kecil digunakan model analisis regresi sederhana. Adapun model yang dimaksud ádalah sebagai berikut :

$\mathrm{Z}=\mathrm{Co}+\mathrm{C} 1 . \mathrm{Y}+\mathrm{ei}$

Dimana: $\mathrm{Z}=$ Pendapatan keluarga; $\mathrm{Y}=$ Keberhasilan usaha $\quad$ (volume usaha); $\mathrm{Co}=$ konstanta; $\mathrm{C} 1=$ Koefisien regresi; ei $=$ error term

Analisis data dengan pendekatan model regresi di atas dibantu dengan perangkat komputer menggunakan análisis statistik SPSS versi-17. Kaidah pengambilan keputusan dari hasil análisis adalah: Jika t-hitung $>$ t $\alpha=0,1$ atau p-value lebih kecil dari 0,10; tolak $\mathrm{H}_{0}$ dan disimpulkan bahwa faktor-faktor yang diteliti berpengaruh terhadap volume usaha dan pendapatan keluarga pengusaha kecil. Jika t-hitung $<\mathrm{t} \alpha=0,1$ atau $\mathrm{p}$-value lebih besar dari 0,10 ; terima $\mathrm{H}_{0}$ dan disimpulkan bahwa faktor-faktor yang diteliti tidak berpengaruh terhadap volume usaha dan pendapatan keluarga pengusaha kecil.

\section{HASIL}

Karakteristik Usaha Kecil di Kota Jambi

Kelompok usaha kecil yang menjadi kajian dalam penelitian ini memiliki sebaran kelompok usaha sebagai berikut:

Tabel 3

Sebaran Kelompok Usaha Kecil Yang Dikaji Dalam Penelitian di Kecamatan Jelutung Kota Jambi.

\begin{tabular}{lrr}
\hline \multicolumn{1}{c}{ Kelompok Usaha } & Jumlah Sampel & Persentase \\
\hline Toko Kelontong & 77 & 83,7 \\
Makanan Ringan & 9 & 9,8 \\
Perabotan & 6 & 6,5 \\
Jumlah & 92 & 100 \\
\hline
\end{tabular}

Sumber: data olahan

Representasi kelompok usaha Toko Kelontong merupakan kelompok usaha kecil terbesar dijumpai di Kecamatan Jelutung Kota Jambi, sehingga jumlah sampel yang terjaring mencapai $83,7 \%$. Selanjutnya secara berturut-turut diikuti oleh kelompok usaha Makanan Ringan dan usaha Perabotan dengan porsi masing-masing sebesar 9,8\% dan 6,5\%. Keberadaan usaha Toko Kelontong dan Makanan Ringan pada umumnya mengambil lokasi yang tersebar di sepanjang jalan-jalan utama (protokol) dan di pasar-pasar tradisional. Para Pedagang Toko Kelontong umumnya menjalankan usahanya pada siang hari sampe malam hari, berkisar antara pukul 8.00 sampai dengan pukul 22.00. Hanya sebagian kecil dari usaha Toko Kelontong yang beraktivitas sampai pukul 17.00 sorre. Sementara usaha Perabotan beraktivitas berkisar antara pukul 8.00 pagi sampai 16.00 sore. Sedangkan usaha Makanan Ringan menjalankan usahanya ada pada siang hari ataupun pada malam hari. Sumber modal usaha kecil di Kecamatan Jelutung Kota Jambi untuk menjalankan usahanya berasal dari modal sendiri dan pinjaman, baik melalui jasa perbankan maupun rentenir. Besarnya modal usaha berkisar antara Rp 10.000.000 - Rp. 75.000.000. Rincian sumber modal usaha para pengusaha kecil disajikan pada tabel di bawah ini.

Tabel 4

Sumber Modal Usaha Kecil di Kecamatan Jelutung Kota Jambi Tahun 2015.

\begin{tabular}{lrr}
\hline \multicolumn{1}{c}{ Sumber Modal } & Jumlah (Orang) & Persen $(\%)$ \\
\hline Modal Sendiri & 35 & 38 \\
Pinjaman & $\underline{57}$ & $\underline{62}$ \\
Bank BRI & 11 & 12 \\
Bank BPR & 20 & 21,7 \\
Rentenir & 26 & 28,3 \\
Jumlah Sampel & 92 & 100 \\
\hline
\end{tabular}

Sumber: data olahan 
Usaha kecil yang menggunakan modal sendiri/keluarga dalam menjalankan usahanya sebanyak 35 orang (38\%). Selebihnya para pengusaha kecil memanfaatkan jasa lembaga keuangan untuk mendapatkan tambahan modal dalam mengembangkan usahanya. Akses pengusaha kecil terhadap lembaga keuangan masih sangat terbatas, yang ditunjukkan dengan kecilnya jumlah para pengusaha kecil memanfaatkan fasilitas pinjaman dari pihak perbankan seperti Bank BRI dan bank-bank kreditur lainnya. Terdapat sebanyak 11 orang (12\%) pengusaha kecil mendapatkan pinjaman dari Bank BRI dengan kisaran nilai pinjaman sebesar 20 hingga 50 juta rupiah. Di antara 11 orang pengusaha kecil yang memanfaatkan fasilitas pinjaman dari Bank BRI, hanya 3 orang saja yang memanfaatkan fasilitas Kredit Usaha Rakyat (KUR) dengan suku bunga yang jauh lebih rendah dibanding pinjaman jenis usaha komersil. Selanjutnya sebanyak 20 orang $(21,7 \%)$ pengusaha kecil mendapatkan pinjaman dari Bank Perkreditan Rakyat dengan kisaran nilai pinjaman antara 30 hingga 60 juta rupiah. Sebagian besar pengusaha kecil, yakni sebanyak 26 orang $(28,3 \%)$ memperoleh pinjaman untuk menambah modal usaha berasal dari jasa rentenir dengan nominal antara 5 hingga 15 juta rupiah. Ditinjau dari aspek pengalaman berusaha, pengusaha kecil di Kecamatan Jelutung Kota Jambi telah menjalankan usahanya antara $2-15$ tahun atau dengan rata-rata 6 tahun. Beberapa di antara usaha kecil tersebut merupakan usaha warisan dari orang tua seperti pengusaha Perabotan (mebel/furniture). Sementara dari aspek tenaga kerja, usaha kecil yang ada menggunakan tenaga kerja keluarga dalam menjalankan usahanya. Aspek tingkat pendidikan formal, usaha kecil di Kecamatan Jelutung Kota Jambi cukup bervariasi, ada yang hanya mengenyam pendidikan Sekolah Dasar (SD) hingga pendidikan tinggi (Sarjana S1). Sebaran pendidikan pengusaha kecil di Kecamatan Jelutung Kota Jambi dapat dilihat pada tabel berikut.

Tabel 5

Tingkat Pendidikan Formal Pengusaha Kecil di Kecamatan Jelutung Kota Jambi.

\begin{tabular}{lrr}
\hline \multicolumn{1}{c}{ Tingkat Pendidikan } & Jumlah (Orang) & Persen $(\%)$ \\
\hline SD & 2 & 2,2 \\
SLTP & 14 & 15,2 \\
SLTA & 70 & 76,1 \\
S1 & 6 & 6,5 \\
Jumlah & 92 & 100 \\
\hline
\end{tabular}

Sumber: data olahan

Dari sebaran tingkat pendidikan formal pengusaha kecil, terdapat 2 orang $(2,2 \%)$ berpendidikan Sekolah Dasar (SD). Sebanyak 14 orang $(15,2 \%)$ adalah berpendidikan SLTP dan sebanyak 70 orang $(76,1 \%)$ berpendidikan formal SLTA. Di antara pengusaha kecil tersebut terdapat sebanyak 6 orang $(6,5 \%)$ menyandang predikat sarjana (S1). Jumlah tanggungan keluarga para pengusaha tergolong kecil yang hanya berkisar $2-4$ orang dengan rata-rata sekitar 3 orang. Pada umumnya yang menjadi tanggungan keluarga dari pengusaha kecil terdiri dari seorang istri dan 1 -2 orang anak. Besarnya volume usaha dari usaha kecil yang terdapat di Kecamatan Jelutung Kota Jambi sangat bervariasi yang berkisar antara 14 juta sampai 79 juta rupiah. Begitu juga dengan pendapatan usaha kecil, bervariasi antara 1,2 juta sampai 8 juta rupiah per bulan.

\section{Faktor-Faktor Yang Mempengaruhi Volume Usaha kecil}

Beberapa faktor yang diduga berpengaruh terhadap volume usaha pada usaha kecil yang terdapat di Kecamatan Jelutung Kota Jambi diuji secara serempak dan secara parsial berbasis komputasi komputer dengan menggunakan perangkat lunak program analisis data (SPSS versi-17). Faktor-faktor (variabel independen) yang diuji pengaruhnya terhadap volume usaha (variabel devenden Y) meliputi yakni; besarnya modal usaha (X1), lamanya menjalankan usaha (X2), tingkat pendidikan formal (X3), jumlah tanggungan keluarga (X4), dan akses terhadap bank (X5). Berdasarkan hasil analisis uji serempak (uji-F) diperoleh nilai Probabilitas $\mathrm{P}=0,0000$. Jika diperoleh nilai $\mathrm{P}<$ 0,10 berarti secara bersama-sama faktor modal, lama berusaha, tingkat pendidikan formal, jumlah tanggungan keluarga dan akses terhadap bank berpengaruh terhadap volume usaha yang dijalankan oleh pengusaha kecil yang terdapat di Kecamatan Jelutung Kota Jambi. Selanjutnya berdasarkan hasil analisis uji secara parsial diketahui bahwa terdapat dua faktor yang berkontribusi secara nyata terhadap volume usaha pada usaha kecil yang terdapat di Kecamatan Jelutung Kota Jambi yakni faktor modal dan tingkat pendidikan formal dengan nilai Probabilitas masingmasing sebesar $\mathrm{P}=0,0000$ dan $0,0893(<$ nilai $\alpha=0,10)$. Sedangkan nilai Probabilitas $\mathrm{P}$ dari faktor-faktor lainnya (lama berusaha, jumlah tanggungan keluarga dan akses usaha kecil terhadap bank) yang diuji mempunyai besaran $\mathrm{P}$ lebih besar dari 0,10, yang berarti tidak berpengaruh terhadap volume usaha pada selang kepercayaan 90\%. Model penduga yang menyatakan hubungan antara volume usaha dengan faktor-faktor yang dikaji dalam penelitian ini diformulasikan dalam model regresi linier berganda sebagai berikut.

$\mathrm{Y}=8403832+1,02 \mathrm{X}_{1}-140583 \mathrm{X}_{2}+270090 \mathrm{X}_{3}-357955 \mathrm{X}_{4}-250145 \mathrm{X}_{5}$

Model penduga di atas, koefisien regresi untuk modal usaha (X1) bernilai positif. Dengan demikian dapat dijelaskan bahwa setiap tambahan modal usaha sebesar satu juta, akan menyebabkan peningkatan volume usaha (Y) 
sebesar 1,02 juta. Selanjutnya dari model penduga tersebut diperoleh nilai koefisien determinasi $\mathrm{R}^{2}$ sebesar 0,9629 ; yang berarti $96,29 \%$ sebaran nilai volume usaha yang diuji ditentukan oleh variabel indevenden yang terlibat dalam pengukuran.

\section{Hubungan Antara Volume Usaha Dengan Pendapatan Keluarga}

Besarnya volume usaha pada studi kasus usaha kecil di Kecamatan Jelutung Kota Jambi berpengaruh secara nyata terhadap pendapatan keluarga pengusaha kecil. Dari hasil analisis uji statistik diperoleh nilai Probabilitas $\mathrm{P}=$ 0,0000 untuk faktor volume usaha (Y). Model penduga bagi hubungan antara volume usaha (Y) dengan pendapatan keluarga pengusaha kecil (Z) diformulasikan dalam bentuk persamaan regresi linier sederhana sebagai berikut.

\section{$\mathrm{Z}=392937+0,08 \mathrm{Y}$}

Model penduga di atas diperoleh nilai koefisien regresi faktor volume usaha bernilai positif. Sehingga dapat dijelaskan suatu hubungan bahwa setiap penambahan satu satuan volume usaha (Y), akan menyebabkan kenaikan pendapatan keluarga pengusaha kecil (Z) sebesar 0,08 satuan. Dari model penduga di atas diketahui bahwa nilai koefisien determinasi R2 sebesar 0,8420 yang berarti 84,2\% sebaran data pendapatan keluarga ditentukan oleh faktor volume usaha. Sedangkan sisanya sebesar $15,8 \%$ oleh pengaruh faktor lain di luar model. Faktor modal dan tingkat pendidikan merupakan variabel yang berkontribusi signifikan terhadap besarnya volume usaha pada usaha kecil di Kecamatan Jelutung Kota Jambi. Dari hasil analisis yang telah dilakukan, penambahan modal usaha masih memungkinkan bagi terjadinya penambahan volume usaha. Begitu pula dengan tingkat pendidikan, perlu ditingkatkan melalui kursus singkat maupun pelatihan-pelatihan dalam upaya menambah pengetahuan berusaha sehingga sumberdaya manusianya lebih baik.

Menyangkut permodalan, pengusaha kecil relatif sedikit yang telah memanfaatkan fasilitas perbankan untuk menambah modal dalam rangka mengembangkan usahanya. Hasil wawancara dengan pengusaha kecil terungkap bahwa kesulitan utama yang mereka hadapi dalam mengembangkan usaha berkaitan dengan modal. Pengusaha kecil sulit membangun akses dengan lembaga perbankan untuk mendapatkan pinjaman. Hal ini karena kurangnya pengetahuan sebagian besar pengusaha kecil tentang prosedur atau tata cara memanfaatkan jasa perbankan maupun persyaratan yang sulit terpenuhi sesuai tuntutan pihak perbankan atau kreditur. Menurut Sri Adiningsih (2003), pada situasi seperti ini, pemerintah perlu membuat program khusus bagi penanganan usaha kecil agar mampu tumbuh dan berkembang serta kokoh. Laporan keuangan menjadi salah satu komponen yang mutlak harus dimiliki oleh usaha kecil jika mereka ingin mengembangkan usaha dengan mengajukan modal kepada para kreditur yang dalam hal ini adalah pihak perbankan. Namun kebiasaan untuk mencatat setiap kegiatan usaha yang terjadi dan menyusun laporan keuangan merupakan hal sulit di kalangan pengusaha kecil. Para pelaku usaha kecil memiliki kebiasaan mencatat transaksi dengan secara sederhana dan tidak lengkap karena hanya memiliki kemampuan sumberdaya tenaga kerja dan waktu yang terbatas. Jadi, laporan keuangan yang dibuat oleh pengusaha kecil pada umumnya hanya semata untuk kalangan sendiri dan cukup sebatas dimengerti oleh pengusaha kecil itu sendiri. Fakta yang ditemui pada usaha kecil hanya mencatat jumlah uang yang diterima dan dikeluarkan, jumlah barang yang dibeli dan dijual, dan jumlah uang/piutang, namun pencatatan itu hanya sebatas pengingat saja dan tidak dengan format yang diinginkan oleh pihak perbankan, akan tetapi tidak dapat dipungkiri bahwa pengusaha kecil dapat mengetahui jumlah modal akhir setiap tahun yang hampir sama jumlahnya jika dicatat dengan sistem akuntansi. Untuk itu, memperbaiki kemampuan sumberdaya manusia dari pengusaha kecil sangat penting melalui pendidikan informal seperti kursus atau pelatihan singkat (Haeruman, 2000).

Mencatat setiap transaksi yang terjadi sangat penting sebagai bahan untuk menyusun laporan keuangan. Jika catatan mengenai transaksi usaha tidak ada, maka laporan keuangan tidak dapat dibuat. Setiap transaksi harus disertai bukti-bukti transaksi yang benar-benar terjadi. Dalam dunia akuntansi, setiap transaksi dicatat dalam buku ( buku jurnal), sehingga transaksi dapat dicatat dengan rapi dan jelas serta efisien, kemudian dimasukkan dalam buku besar yang meliputi buku kas, buku pembelian tunai dan kredit, buku penjualan tunai dan kredit, buku piutang dan buku utang yang mana buku-buku tersebut memiliki hubungan satu dengan yang lain. Proses pencatatan dengan sistem akuntansi akan menunjukkan bahwa setiap transaksi akan mempengaruhi pencatatan pada buku yang satu dengan buku lainnya, dengan catatan-catatan yang tertera dalam tiap buku maka dapat dibuat sebuah laporan keuangan secara sederhana tetapi dapat diterima oleh berbagai pihak antara lain perbankan. Di samping itu juga dapat membantu pengusaha dalam proses pengajuan kredit usaha, keputusan investasi dan juga keputusan pengembangan usaha serta sebagai alat analisis kinerja perusahaan melalui berbagai ratio keuangan. Proses pencatatan keuangan yang dibuat oleh sebagian besar usaha kecil di Kecamatan Jelutung belum mengikuti sistem akuntansi, sehingga hasil akhir dari pencatatan tersebut tidak bisa disusun dalam bentuk laporan keuangan sesuai dengan proses akuntansi. Oleh karena itu tidak bisa dipakai sebagai bahan penilaian kinerja keuangan suatu usaha. Menurut Darsono dan Ashari (2005) kegunaan laporan keuangan yang dihasilkan oleh akuntansi adalah untuk : (a) alat pertanggungjawaban, dan (b) untuk memprediksi arus kas dan alat pengambilan keputusan, serta (c) bagi pihak perbankan menjadi persyaratan dalam menilai kemampuan finansial usaha kecil. Laporan keuangan bukan hanya sekedar sebagai catatan historis, melainkan 
memiliki efek untuk prediksi ke depan, sesuatu yang sangat diperlukan untuk menjalankan bisnis. Selain mempermudah pengusaha menghitung utang, piutang ataupun laba rugi usahanya, adanya laporan keuangan yang lengkap memudahkan pengusaha kecil untuk melakukan pinjaman kepada pihak Bank, Koperasi ataupun menjadi mitra binaan perusahaan BUMN.

Hingga saat ini, usaha kecil di Kecamatan Jelutung Kota Jambi belum pernah menjalin suatu bentuk kemitraan dengan pihak manapun termasuk perusahaan BUMN yang ada di Kota Jambi. Usaha-usaha kecil yang ada tumbuh dan berkembang berdasarkan naluri bisnis dan pengalaman turun-temurun dari pengelolanya. Padahal membangun kemitraan antara usaha kecil dengan berbagai pihak sangatlah penting demi terwujudnya usaha kecil yang maju, kuat dan produktif. Karena tak dapat dipungkiri bahwa usaha kecil mempunyai peranan setrategis dalam upaya mendukung perekonomian nasional khususnya dalam pemerataan dan kesempatan kerja serta berkontribusi nyata bagi perkembangan ekonomi nasional pada umumnya. Oleh karena itu, pada kenyataan sedemikian ini kehadiran pemerintah melalui instansi terkait harus selalu berupaya menciptakan link kemitraan antara usaha kecil sebagai binaan dengan perusahaan BUMN, perusahaan swasta nasional dan lembaga perbankan melalui jalur antara lain pelatihan ataupun bantuan modal berupa kredit dengan tingkat suku bunga yang sangat minim untuk mengatasi kemampuan finansial dan pengetahuan dasar pengembangan usaha yang relatif kurang memadai. Untuk saat ini, yang terpenting bagi pengusaha kecil adalah suatu kemudahan mendapatkan fasilitas pinjaman dari lembaga kreditur. Pengusaha kecil berharap agar pemerintah dapat memberi berbagai kelonggaran terkait prosedur peminjaman modal usaha yang semestinya harus dibedakan dengan persyaratan yang umum berlaku. Jika dalam memperoleh pinjaman disyaratkan dengan agunan/jaminan, pengusaha kecil berharap tidak harus terbebani lagi dengan prosedur yang rumit dan dianggap bertele-tele. Prosedur yang rumit menjalin kerjasama dengan lembaga-lembaga kreditur atau perbankan untuk mendapatkan modal usaha menyebabkan pengusaha kecil dengan terpaksa memanfaatkan jasa rentenir dengan agunan dan bunga pinjaman yang sangat memberatkan. Berdasarkan hasil wawancara dengan pengusaha kecil, bunga pinjaman pada bank-bank BUMN jauh lebih kecil dibanding BPR. Akan tetapi akses terhadap bank-bank BUMN untuk mendapatkan pinjaman sepertinya dipersulit, dan jika pun mendapatkan pinjaman, jumlah pinjaman yang didapat cukup jauh di bawah yang diajukan pengusaha kecil. Oleh sebab itu, pengusaha kecil lebih memilih mengajukan pinjaman pada bank-bank BPR meskipun dengan bunga yang jauh lebih tinggi. Berkaitan dengan modal usaha ini, pengusaha kecil ini menginginkan ada perhatian khusus dari pemerintah. Hal ini bertujuan agar pengusaha kecil tidak memilih jalan pintas dan terperangkap dalam jeratan rentenir. Sementara binamitra yang didambakan sebagai solusi tempat peminjaman modal usaha belum terjalin dengan pengusaha kecil.

Sebagaimana umumnya kondisi usaha kecil di Indonesia, menurut Haeruman (2000), tantangan bagi dunia usaha, terutama pengembangan UKM, mencakup aspek yang luas, antara lain : 1. Peningkatan kualitas SDM dalam hal kemampuan manajemen, organisasi dan teknologi, 2. Kompetensi kewirausahaan, 3. Akses yang lebih luas terhadap permodalan, 4. Informasi pasar yang transparan, 5. Faktor input produksi lainnya, dan 6. Iklim usaha yang sehat yang mendukung inovasi, kewirausahaan dan praktek bisnis serta persaingan yang sehat. Sementara itu, rencana pemerintah untuk memberdayakan ekonomi masyarakat kecil melalui program-program pembangunan usaha kecil dan menengah adalah satu hal yang semestinya, walaupun di dalam tataran konsep (termasuk legal aspect) dan implementasinya masih mengalami kekurangan di sana sini. Sebagai misal, konsep usaha kecil dan menengah tidaklah benar-benar melingkupi secara keseluruhan masyarakat kecil tadi. Bagaimana mendefinisikan usaha kecil yang benarbenar kecil atau mendefinisikan rakyat kecil seringkali masih bias. Dan malangnya, jumlah mereka yang tidak/kurang terdefinisikan dalam rencana-rencana pembangunan nasional tersebut berjumlah sangat besar. Salah satu pembenahan utama yang diperlukan adalah dari aspek regulasinya. Usaha kecil idealnya memang membutuhkan peran dan campur tangan pemerintah dalam peningkatan kemampuan bersaing. Namun yang perlu diperhatikan adalah bahwa kemampuan di sini bukan dalam arti kemampuan untuk bersaing dengan usaha besar, tetapi lebih pada kemampuan untuk memprediksi lingkungan usaha dan kemampuan untuk mengantisipasi kondisi lingkungan tersebut (Sri Adiningsih, 2003).

\section{SIMPULAN}

Studi kasus yang dilakukan terhadap usaha kecil yang terdapat di Kecamatan Jelutung Kota Jambi diperoleh kesimpulan sebagai berikut:

1. Faktor modal usaha dan tingkat pendidikan formal merupakan faktor penentu yang berpengaruh nyata terhadap volume usaha pengusaha kecil di Kecamatan Jelutung Kota Jambi.

2. Meningkatnya volume usaha, berpengaruh nyata terhadap peningkatan pendapatan keluarga pengusaha kecil di Kecamatan Jelutung Kota Jambi.

\section{DAFTAR PUSTAKA}

Darsono dan Ashari, 2005. Pedoman Praktis Memahami Laporan Keuangan, Yogyakarta.

Haeruman H, 2000. Peningkatan Daya Saing Industri Kecil Untuk Mendukung Program PEL. Makalah Seminar 
Peningkatan Daya Saing, Graha Sukofindo, Jakarta.

Sri Adingingsih, 2003. Regulasi dan Revitalisasi Usaha Kecil dan Menengah, disampaikan pada Seminar Pembangunan Hukum Nasional VIII di Bali, 14-18 Juli 2003.

Umar, Husein, 2004. Desain Penelitian Manajemen Strategik. Penerbit PT Rajawaji Grafindo Persada.

Walpole, R.E., 2001. Pengantar Statistika. Terjemahan : Ir. Bambang Sumantri. Ed. 3., Gramedia Pustaka Utama, Jakarta. 